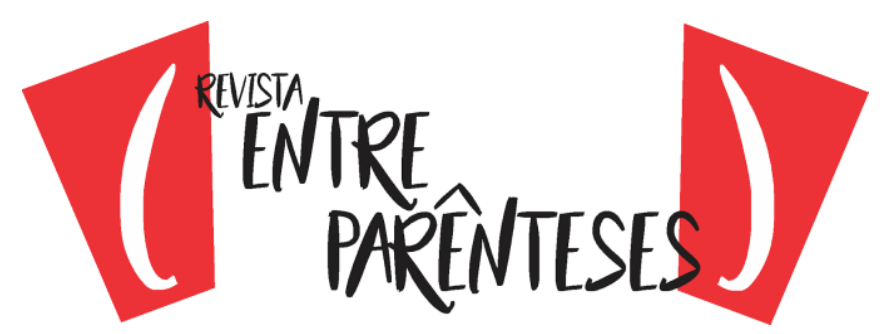

\title{
VIOLÊNCIA SIMBÓLICA, ESTRATIFICAÇÃO SOCIAL E LITERATURA: A RELAÇÃO ORDEM/DESORDEM EM “DEDO- DURO”, DE JOÃO ANTÔNIO
}

\author{
Leandro de Oliveira Lopes ${ }^{1}$ \\ Universidade Federal de São Carlos \\ lopes.leandrodeoliveira@gmail.com
}

Resumo: No "Corpo-a-corpo com a vida" (1975), considerado o manifesto de sua literatura, João Antônio exalta a necessidade de nossas obras lidarem com o povo e com o fato social brasileiro. Para ele, a literatura brasileira deveria tratar do levante e da melhoria desse povo, sendo este o seu principal motivo de ser. Partindo deste pressuposto, analisamos o conto "Dedo-duro" (1982) pretendendo demonstrar, segundo as premissas expostas por Jessé Souza (2009), na primeira e na segunda história do texto (PIGLIA, 2004), uma possível manifestação da violência simbólica que afeta e estratifica nossas classes sociais. Argumentamos que se aplicarmos uma releitura dos conceitos de ordem e desordem (CANDIDO, 1970) seremos capazes de enxergar, no texto literário, a manifestação dessa violência simbólica em atuação para definir a posição social das personagens; e, analogicamente, também a de suas representantes na vida fora dos livros. Essa prática, se comprovada, torna interno um elemento que, externo ao texto, permite que a sociedade brasileira continue organizada segundo a lógica social que ajuda a explicar a manutenção da desigualdade social brasileira. Essa lógica, uma vez interna à obra, atua no texto e em sua organização estética, fazendo do movimento entre ordem e desordem social sua característica principal.

Palavras-chave: violência social; violência simbólica; desordem social; João Antonio

Abstract: In the "Corpo-a-corpo com a vida" (1975), considered the manifesto of his literature, João Antonio exalts the need for our literature to deal with the people and the Brazilian social fact. For him, Brazilian literature must deal with the improvement of its people, the main reason of our literature. In this study, we analyze the short-story "Dedo-duro" (1982) aiming to demonstrate, according to the premises established by Jessé Souza (2009), in the first and second story of the text (PIGLIA, 2004), how are manifested the symbolic violence that affects and stratify our social classes. We argue that if we apply a rereading of the concepts of order and disorder (CANDIDO, 1970), we can see, in the text, the aesthetic manifestation of that symbolic violence in acting to define the social position of its characters; and, analogically, also of their representatives in the life outside the books. This practice, if proven, renders internal an element that, external to the text, allows Brazilian society to remain organized according to the social logic that helps to explain the maintenance of Brazilian social inequality. This logic, once internal, acts in the text and in its aesthetic organization, making the movement between order and social disorder its main characteristic.

Key-words: social violence; symbolic violence; social disorder; João Antonio.

Resumen: En el "Corpo-a-corpo com a vida" (1975), considerado el manifiesto de su literatura, João Antonio exalta la necesidad de nuestra literatura en lidiar con el pueblo y el hecho social brasileño. Para él, la literatura brasileña debería lidiar con el levantamiento y el mejoramiento de su pueblo; el principal motivo de nuestra literatura. En este estudio, analizamos el cuento "Dedo-duro" (1982), con el objetivo de demostrar, en acuerdo con las premisas expuestas por Jessé Souza (2009), en la primera y segunda historia de este cuento (PIGLIA, 2004), la manifestación de la violencia simbólica

1 Doutorando e Mestre em Estudos de Literatura pelo Programa de Pós-Graduação em Estudos de Literatura, PPGLit, da Universidade Federal de São Carlos, UFSCar. Jornalista graduado pelo Centro Universitário FIAM-FAAM. 


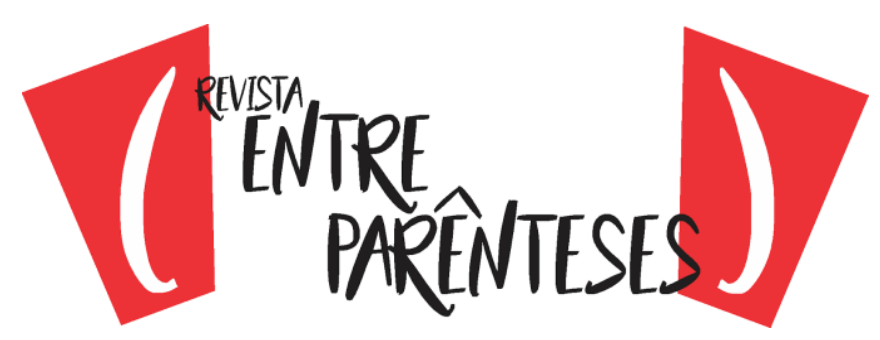

que afecta y estratifica nuestras clases sociales. Argumentamos que si aplicamos una relectura de los conceptos de orden y desorden (CANDIDO, 1970) seremos capaces de ver, en el texto literario, la manifestación estética de esa violencia simbólica en actuación para definir la posición social de los personajes. Esta práctica, si comprobada, hace interno un elemento que, externo al texto, permite que la sociedad brasileña continúe organizada según la lógica social que ayuda a explicar el mantenimiento de la desigualdad social brasileña. Esta lógica, una vez interna a la obra, actúa en el texto y en su organización estética, haciendo del movimiento entre orden y desorden social su característica principal.

Palabras clave: violencia social; violencia simbólica; desorden social; João Antonio.

\section{"A briga é essa. Ou nenhuma": corpo-a-corpo com a desordem social}

A citação a que este subtítulo faz referência, destacada entre aspas, foi retirada do "Corpo-a-corpo com a vida" (ANTÔNIO, 1975, p. 146), o manifesto literário de João Antônio. O texto, publicado em 1975 no Malhação do Judas Carioca, dá diretrizes de como ele enxergava a literatura e o ato de escrever, e serve de parâmetro para o que se viu em sua obra; mesmo que se considere a parte predecessora à ele (SILVA, 2015, p. 2). João Antônio, que estreou na literatura em 1963 com Malagueta, Perus e Bacanaço², tinha no povo brasileiro o seu único foco. Para ele, quando preocupados com a "forma, sob a denominação de um 'ismo' qualquer" (ANTÔNIO, 1975, p. 143), nossos escritores se distanciavam de certas "faixas da vida brasileira" (ANTÔNIO, 1975, p. 143), e dessa forma depreciavam nossa realidade social - que deveria ser a missão única do texto. João Antônio acreditava que o motivo de ser de nossa literatura era a atuação em favor da melhoria da vida do povo brasileiro. Um trabalho, em texto literário (ou jornalístico ${ }^{3}$ ), em favor do povo; do levante de suas dificuldades e no melhoramento de suas condições.

O caminho é claro e, também por isso, difícil - sem grandes mistérios e escolas. Um corpo-a-corpo com a vida brasileira. Uma literatura que se rale nos fatos e não que rele neles. Nisso, a sua principal

\footnotetext{
2 Pelo qual recebeu os prêmios Jabuti de "melhor livro de contos" e de "autor revelação"; embora não haja, no site do Prêmio Jabuti, registros do prêmio de autor revelação do ano de 1964, são praticamente unânimes as fontes a respeito de João Antônio que atribuem esse prêmio ao autor, fato que o colocaria como o primeiro escritor estreante a vencer dois prêmios Jabuti no mesmo ano.

3 João Antônio, que também foi jornalista, sugere o jornalismo literário, chegando a citar Gay Talese, como um caminho possível nessa procura por um texto interventor.
} 


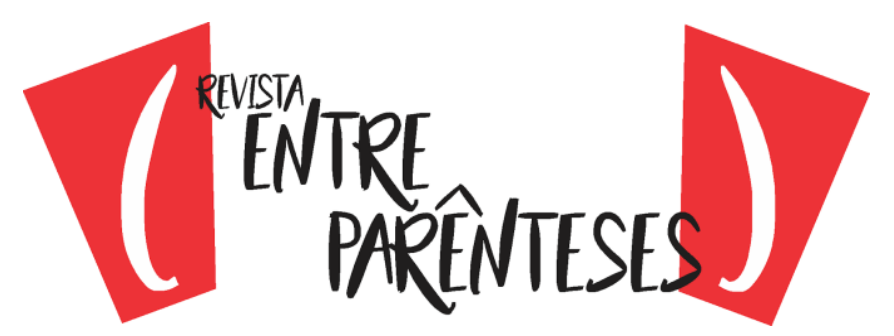

missão - ser a estratificação da vida de um povo e participar da melhoria e da modificação desse povo. Corpo-a-corpo. A briga é essa. Ou nenhuma (ANTÔNIO, 1975, p. 146).

Atuar no levante de nossas inconsistências sociais e colaborar no combate a elas. Esta era a briga da literatura brasileira. Assim, é possível afirmar que o texto de "Corpo-a-corpo com a vida" traz em si um "evidente aspecto político, de intervenção ou marcação de posições no campo literário brasileiro, com o horizonte de influir, dentro de suas possibilidades e de sua arma específica - o texto -, na crítica, estudo, denúncia e desnudamento dos problemas nacionais" (SILVA, 2015 , p. 2), pois para que sua literatura fosse propositiva - sendo essa a arma de que dispunha o escritor neste confronto social, João Antônio defendia que o autor precisaria estar diretamente ligado ao fato social. Era preciso participar, ativamente, politicamente até (enquanto escritor), da realidade do povo brasileiro. "Como um bandido falando de bandidos" (ANTÔNIO, 1975, p. 146). Por um projeto de escritura de dentro para fora, que, participando da realidade social do povo, fosse capaz de responder, através daquele mesmo olhar, sem distanciamento.

Não será absolutamente necessário, para compreender - uma palavra superada; leia-se, por favor, enfrentar - o marginalismo individual dos que se debatem no futebol ou na polícia, alguém que assuma o mesmo gangsterismo, um semelhante (mas com visão crítica) individualismo? Um gangsterismo, um individualismo, um individualismo ao menos experimental. Que, ao escrever, dê a mesma porrada, como repórter, escritor, etc., que o bandido, 0 jogador, o traficante, o bicheiro e, especialmente e isso tudo - herói dão para sobreviver. Assim, uma literatura de murro e porrada. Um corpo-a-corpo com a vida (ANTÔNIO, 1975, p. 148).

É assim que João Antônio se coloca ao lado de suas personagens, e é (também) por isso que ficou conhecido como o autor de indivíduos marginalizados socialmente, como prostitutas; mendigos; bandidos; moleques de rua e outros aos quais dedicava seus textos. Acreditando no povo como a missão de nossa literatura, identificou nessa camada da sociedade a necessidade de agir. No mesmo "Corpo-acorpo com a vida", falando de Malagueta, Perus e Bacanaço (1963), esclareceu esse sentimento de participação: 


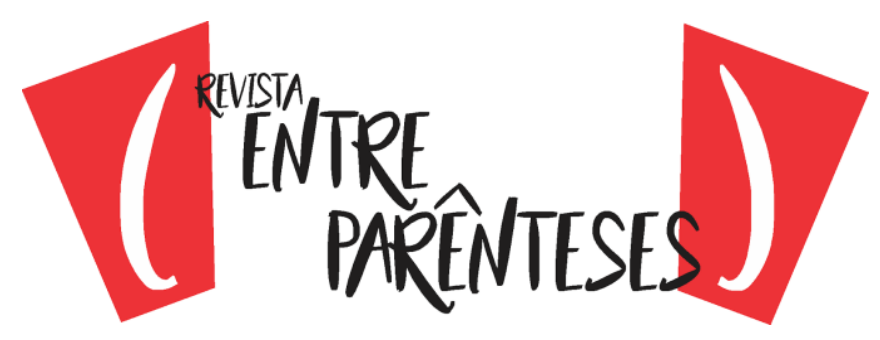

O elemento que mais me leva a acreditar em Malagueta, Perus e Bacanaço como coisa viva se arruma exatamente no fato de que vi meus jogadores de sinuca, viradores, vadios, vagabundos, merdunchos do ponto de vista deles mesmo. E não do escritor. No meu caso particular, até por questões de vida, não poderia enfrentálos sob nenhuma outra ótica (ANTÔNIO, 1975, p. 150).

João Antônio não podia fugir de colocar-se ao lado dessas personagens porque sua formação - seja como cidadão, seja como escritor - se deu em conformidade com essa realidade social. Era filho de João Antônio Ferreira português de Trás-os-Montes, do nordeste de Portugal, e Irene Gomes Ferreira mulata carioca, semianalfabeta e descendente de escravos. A família de sua mãe mudou-se do Rio de Janeiro para São Paulo em 1929, por efeito da grande crise econômica vivida naquele momento. A família de seu pai estava em São Paulo desde 1913. Sempre em busca de novas oportunidades, João Antônio (pai) foi motorista, operário e até sócio de uma pedreira ${ }^{4}$, mas passou a maior parte de seus anos como dono de armazéns nas regiões suburbanas de São Paulo - com especial destaque para o distrito de Presidente Altino, em Osasco, local onde seu pai e seus tios, também vindos de Portugal, compraram lotes de terrenos. Sua mãe, Irene, foi operária de um frigorífico e dona de casa.

Em sua juventude João Antônio considerava a leitura sua principal fonte de conexão com a arte. No desenvolvimento desse gosto, alimentou a paixão por escrever. Ainda na pré-adolescência, como destacou Clara Avilla Ornellas, publicou textos na revista infanto juvenil $O$ Crisol. Textos pelos quais recebia livros como pagamento.

O livro que mais me marcou nesse período [de colaboração com $\mathrm{O}$ Crisol] foi 'Esopo, o contador de histórias', um livro de Ofélia e Nerbal Fontes, editado pela Melhoramentos. O Esopo, aquele escravo frígio e tartamudo que conseguia, através de uma capacidade política de vida, sobreviver no meio daquele mundo escravo, e que acaba conseguindo a liberdade, e que acaba, inclusive, tomando posições em defesa da liberdade e da justiça, e que por isso mesmo ele acaba

4 Foi enquanto João Antônio (pai) era sócio da pedreira que a família Ferreira viveu seu melhor momento financeiro. Acabou traído por um sócio e perdeu tudo a que tinha direito. 


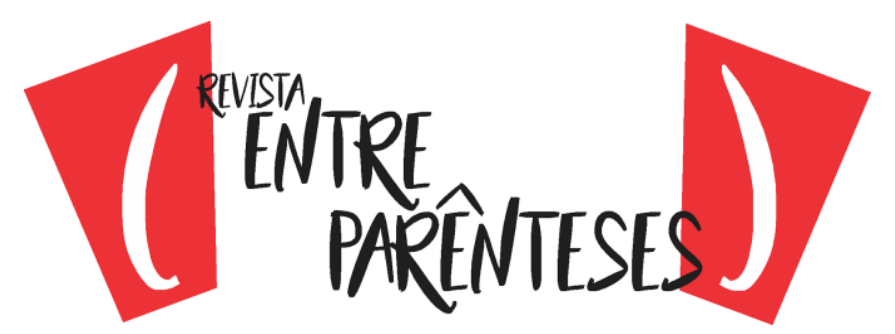

jogado num abismo. Aquele cara mexeu muito não apenas com minha formação literária, mas também com minha formação como gente. Eu sentia assim uma angústia da justiça. Eu achava uma sacanagem jogarem aquele homem num abismo. Hoje, talvez eu ache que não seja só o Esopo, mas foi por aí que eu desandei por esse negócio de literatura (ACUIO et al., 1978, p.1 apud ORNELLAS, 2011, p. 147).

É certo dizer que a proximidade com dada situação ou determinada experiência de vida, por si só, não fazem literatura. Não basta ser nascido e criado no subúrbio paulistano e defender como necessária uma aproximação de texto e povo para que seja feita uma literatura que de fato se aproxime dessa camada social. O local em que se comprova tanto a aproximação quanto o caráter de caráter político e interventor do texto literário é a literatura em si, o próprio texto literário. Pesquisas como a de Regina Dalcastagné, "Literatura brasileira: um território contestado" (2012), tratam do perfil social do autor brasileiro e evidenciam uma supremacia nacional de homens brancos, heterossexuais e de classe média, aclarando uma realidade que impede que outros escritores tomem a caneta à mão. Pois não obstante essa dificuldade, o texto de João Antônio, objeto de análise deste estudo, se sustenta como representante de uma tradição em que estão presentes autores como Oswald de Andrade, Lima Barreto, Graciliano Ramos, e mais recentemente Ferréz, com sua "Literatura marginal" justamente por causa de seu aspecto literário.

Uma das coisas mais importantes da ficção literária é a possibilidade de "dar voz", de mostrar em pé de igualdade os indivíduos de todas as classes e grupos, permitindo aos excluídos exprimirem o teor da sua humanidade, que de outro modo não poderia ser verificada. Isso é possível quando o escritor, como João Antônio, sabe esposar a intimidade, a essência daqueles que a sociedade marginaliza, pois ele faz com que existam, acima de sua triste realidade. [...] Ele é um verdadeiro descobridor, ao desvendar o drama dos deserdados que fervilham no submundo; dos que vivem das lambujens da vida e ele traz com a força da sua arte ao nível da nossa consciência, isto é, a consciência dos que estão do lado favorável, o lado dos que excluem (CANDIDO, 2012, p. 581). 


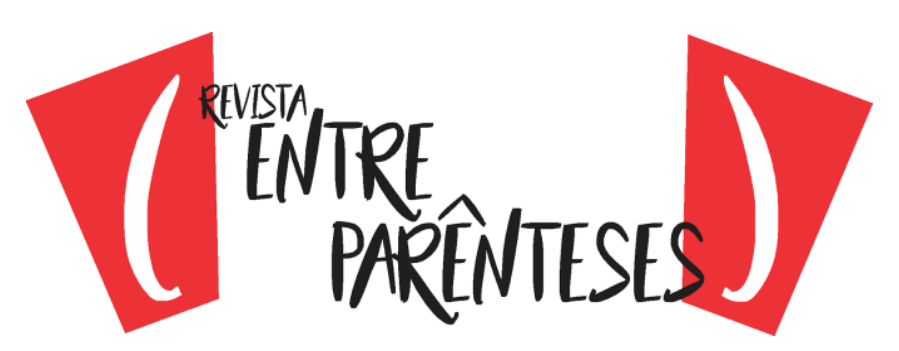

Antonio Candido, no ensaio "Na noite enxovalhada", ensaio originalmente publicado em $1996^{5}$, chegou a dizer que João Antônio "faz para as esferas malditas da sociedade urbana o que Guimarães Rosa fez para o mundo do sertão, isto é, elabora uma linguagem que parece brotar espontaneamente do meio em que é usada, mas na verdade se torna língua geral dos homens" (CANDIDO, 2012, p. 582). Ou seja, a qualidade do que mantém a literatura de João Antônio como representante dessa classe desprivilegiada é o seu próprio texto literário. "Fui percebendo que só se pode fazer arte se for com pele, vísceras, arrebatando o interior. Percebi também que eu tinha um tema - a malandragem" (ANTONIO, 2012, p. 583).

O mesmo Antonio Candido, ao tratar do que ele chamou de "realismo feroz", afirma que, nesse viés, de maneira positiva, em narrativas em primeira pessoa "a brutalidade da situação é transmitida pela brutalidade de seu agente (personagem), ao qual se identifica a voz narrativa, que assim descarta qualquer interrupção ou contraste crítico entre narrador e matéria narrada" (CANDIDO, 2006, p. 257), isso porque dessa forma não há distanciamento entre o fato narrado e a condição social de seu escritor, que de outra maneira poderia se colocar como se em uma suposta posição superior ao do outro que ele trata em literatura. "O narrador, personagem central, não tem acesso ao estado mental das demais personagens. Narra de um centro fixo, limitado quase que exclusivamente às suas percepções, pensamentos e sentimentos" (LEITE, 1985, p. 43). Característica que também se aplica ao texto de João Antônio.

Esta característica é devida a uma espécie de neutralidade estratégica, que dá destaque ao real, sobretudo porque os contos são escritos numa prosa dura, reduzida às frases mínimas, rejeitando qualquer 'elegância' e, por isso mesmo, adequada para representar a força da vida (CANDIDO, 2012, p. 578).

\footnotetext{
5 Texto publicado para a ocasião da morte de João Antônio, em outubro de 1966, sob o título "Ficcionista é 'um verdadeiro descobridor'. O Estado de S. Paulo, ano XVII, n.844, nov. 1996. Suplemento Cultura, p.II. Republicado como "Na noite enxovalhada", in Antonio Arnoni Prado, Maria Eugenia Boaventura e Orna Messer Levin (orgs.). Remate de males, n. 19, Campina: IEL Unicamp, 1999, p.83-88. (ANTONIO, 2012, p. 582).
} 


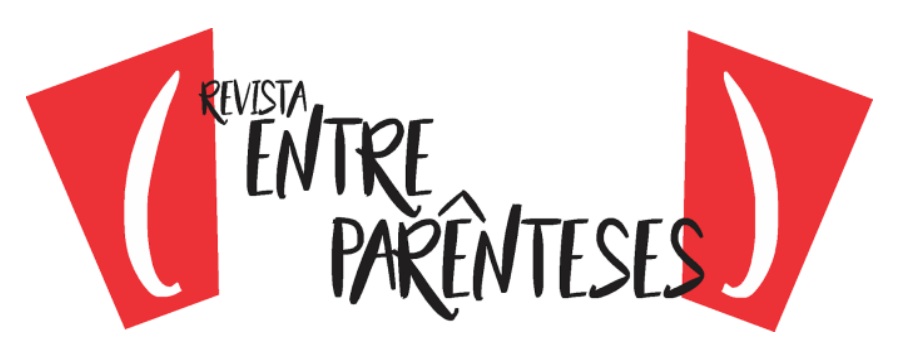

Como, por exemplo, em

Se não tenho nada a espiar, depois de ficar até sol alto na cama, preguiçando, baixo nos salões de sinuca, entre merduchos e ventanas, onde posso cheiras enviesado um e outro serviço bom e ainda, cavando, morder alguma grana dos cobras ganhadores no jogo. A minha estia. Que os tacos vivem só da sinuca e precisam estar limpões e em liberdade para o joguinho. Então, têm de me pagar pedágio. Ali, devo ser temido e, ao mesmo tempo, detestado; afinal, além de explorar o meu tutu não ponho no fogo do jogo. Isso, o nojo, a raiva represada, a gana que me têm, não está me dizendo nada. Aperto a cambada e mordo (ANTÔNIO, 2012, p. 369).

E é justamente neste ponto que começa a se desenhar o conceito de desordem social. Isso porque a "neutralidade estratégica" de que fala Candido representa, ao mesmo tempo que neutralidade de discurso do narrador, uma escolha

[...] por traduzir a força de uma camada social desprivilegiada aos olhos dessa classe média que oprime, pelo viés e perspectiva única dessa mesma camada social oprimida. Essa é a opção de João Antônio pela desordem social em literatura. A escolha que fez ao longo de sua obra e que escancarou no "Corpo-a-corpo com a vida". Como uma inversão da "Dialética da malandragem", de Antônio Candido, a desordem é protagonista e caminho natural, a ordem é apenas um simulacro e quase não aparece. Em seu lugar há uma ordem aparente, disfarçada, mas, no fundo, também desordem (AUTOR, 2017).

Os conceitos de ordem e desordem (CANDIDO, 1970) sugerem um entendimento possível a respeito da organização social brasileira da primeira metade do século XIX. O ensaio, intitulado "Dialética da malandragem", apresenta uma proposta de interpretação do livro Memórias de um sargento de milícias (18531854), de Manuel Antônio de Almeida. Candido defende que, como suas correspondentes na vida fora dos livros, as personagens da obra transitam entre polos, o da ordem e o da desordem; dando forma a um movimento social da época. "Bem entendido, esta unilateralidade é um feito crítico, pois vê mais onde parecia haver menos e confere à obra um alcance que ela talvez nem pretendesse, mas que - uma vez lido o ensaio - de fato é seu" (SCHWARZ, 1979, p. 131). No estudo, o 


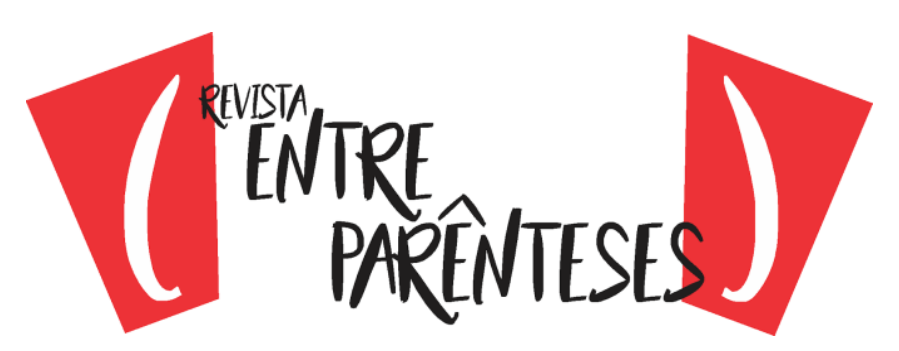

Memórias de um sargento de milícias é organizado mediante uma linha equatorial que separa os personagens e as ações que representam a ordem daquelas que, em oposição, representam a desordem, com Leonardo Filho, o protagonista do livro, transitando entre esses dois polos distintos. Ora na ordem ora na desordem, Leonardo caracteriza-se como um malandro que "pratica a astúcia pela astúcia", "manifestando um amor pelo jogo em si" (CANDIDO, 1970, p. 69). E nessa distinção é que se explica a movimentação que dá forma ao que seria o malandro brasileiro: sujeito que se movimenta entre o lícito e o ilícito e tomando proveito das situações. $A$ ordem, durante todo o estudo, atrelada à manutenção das leis, e a desordem, em contraponto, à quebra delas. A relação entre os dois polos, Candido pontua, se manifesta com mais intensidade nos momentos em que essa organização deixa de transparecer como um informe descritivo intencionalmente posicionado pelo autor e passa a se desenvolver na dinâmica de acontecimentos do próprio livro, como se atuasse na organização interna de seu próprio entrecho.

A respeito disso, Roberto Schwarz explica que

[...] a dialética de ordem e desordem é um princípio de generalização que organiza em profundidade tanto os dados da realidade quanto os da ficção (sejam ou não documentários), dando-Ihes inteligibilidade. Trata-se de uma generalidade que participa igualmente da realidade e da ficção: está nas duas, encontram nela a sua dimensão comum. Assim, o dado ficcional não vem diretamente do dado real, nem é deste que o sentimento da realidade na ficção depende, embora o pressuponha. Depende de princípios mediadores, geralmente ocultos, que estruturam a obra e graças aos quais se tornam coerentes as duas séries, a real e a fictícia (SCHWARZ, 1979, p. 131).

Nas palavras do próprio Candido, não é a "[...] representação dos dados concretos particulares que produz na ficção o senso da realidade; mas sim a sugestão de uma certa generalidade, que olha para os dois lados e dá consistência tanto aos dados particulares do real quanto aos dados do mundo fictício" (CANDIDO, 1970, p. 72). Isso quer dizer que

A força de convicção do livro depende pois essencialmente de certos pressupostos de fatura, que ordenam a camada superficial dos 


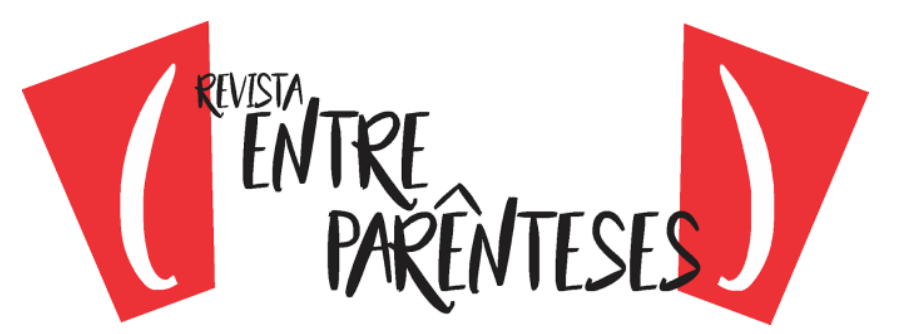

dados. Estes precisam ser encarados como elementos de composição, não como informes proporcionados pelo autor, pois neste caso estaríamos reduzindo o romance a uma série de quadros descritivos de costumes do tempo. [...] A partir do capítulo 28 a linha do filho domina absolutamente e a narrativa, superando as descrições estáticas, amaina a inclusão frequente de usos e costumes, dissolvendo-os na dinâmica dos acontecimentos. Sendo assim, é provável que a impressão de realidade comunicada pelo livro não venha essencialmente dos informes, aliás relativamente limitados, sobre a sociedade carioca do tempo do Rei Velho. Decorre de uma visão mais profunda, embora instintiva, da função, ou "destino" das pessoas nessas sociedades; tanto assim que o real adquire plena força quando é parte integrante do ato e componente das situações (CANDIDO, 1970, p. 70).

A discussão a respeito do real e do fictício, para além da já bastante debatida verossimilhança versus verdade, é importante porque explica que o movimento entre a ordem e a desordem, como a sugestão social da qual levantaremos hipótese, se manifesta não no plano descritivo da obra, mas sim, como também é na vida fora dos livros, nas relações entre pessoas, fictícias ou não.

A linha equatorial que divide as personagens da maneira como Candido procurava entendê-las funciona como mediadora entre um polo e outro, tendo o da ordem sempre certo ar de positividade e o jogo entre eles se dá na medida em que as pessoas transitam entre os dois extremos e fazem "[...] coisas que poderiam ser qualificadas como reprováveis, mas [...] também outras dignas de louvor, que as compensam" (CANDIDO, 1970, p. 84). Para ele, o malandro é aquele que se movimenta entre os dois polos, mas sempre retornando e fazendo da ordem seu caminho natural. No livro, funciona assim com o pai do protagonista Leonardo Filho, Leonardo Pataca, que "faz parte da ordem, como oficial de justiça" (CANDIDO, 1970, p. 78), com sua mãe, Maria da Hortaliça, porque apesar de ilegítima, sua relação com Leonardo Pataca é "habitual e quase normal segundo os costumes do tempo e da classe" (CANDIDO, 1970, p. 78).

Nossa proposição para a literatura de João Antônio, e para a representação social da qual acreditamos fazer parte, vai no sentido oposto. A desordem social, em contraponto à ordem vigente, é o caminho natural tanto do texto de João Antônio, como das pessoas a que suas personagens fazem alusão. 


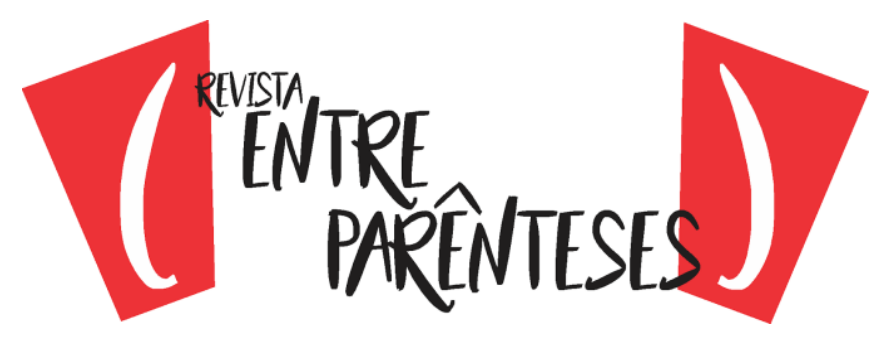

Suscitamos a hipótese de a dialética de Candido contemplar, para além de uma organização em que se relacionem a ordem e a desordem, também uma estratificação social que separa, nestes mesmos polos, classes sociais distintas divididas entre aqueles que se beneficiam do sistema vigente, os opressores, e aqueles que são, por esse mesmo sistema, inferiorizados socialmente, os oprimidos. Assim, se nos permitirmos a aplicação desse novo entendimento aos textos de João Antônio, poderemos comprovar a escolha do autor por uma espécie de desordem social brasileira e, ao mesmo tempo, atribuir a seus textos o viés político de denúncia que ele entendia como necessário (AUTOR, 2017).

Os personagens de João Antônio, normalmente marginalizados, são representações de pessoas de carne e osso que passam suas vidas à margem daquilo que nós, os privilegiados, consideramos como normal e correto.

Ele [João Antônio] é um verdadeiro descobridor, ao desvendar o drama dos deserdados que fervilham no submundo; dos que vivem das lambujens da vida e ele traz com a força da sua arte ao nível da nossa consciência, isto é, a consciência dos que estão do lado favorável, o lado dos que excluem (CANDIDO, 2012, p. 581).

A desordem social, da maneira como suscitamos entendê-la, atua justamente na diferenciação entre os privilegiados, aqueles que, como nós, estão do lado favorável, lado dos que excluem, lado da ordem social, daqueles que, em contrapartida, são excluídos e marginalizados, marcados como desordem social. Este entendimento difere da dialética da malandragem porque naquela a linha que divide um polo e outro é a linha da lei e dos costumes, sempre muito nítida e identificável, enquanto nessa, à medida que nos aprofundamos, a linha parece esconder-se, parece simular sua presença. Linha que pretende naturalizar a diferença que há entre aqueles que podem e os que não podem ir ao dentista para uma consulta de rotina.

O processo de modernização brasileiro constitui não apenas as novas classes sociais modernas que se apropriam diferencialmente dos capitais cultural e econômico. Ele constitui também uma classe inteira de indivíduos, não só sem capital cultural nem econômico em qualquer instância significativa, mas desprovida, esse é o aspecto fundamental, das precondições sociais morais e culturais que 


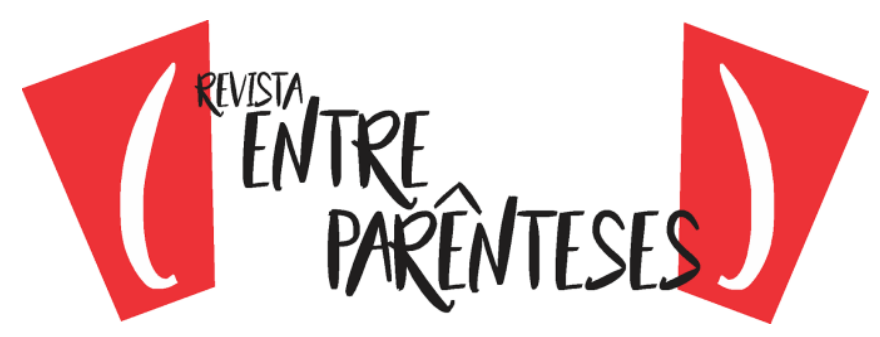

permitem essa apropriação. É essa classe social que designamos neste livro de "ralé" estrutural, não para "ofender" essas pessoas já tão sofridas e humilhadas, mas para chamar a atenção, provocativamente, para nosso maior conflito social e político: o abandono social e político, "consentido por toda a sociedade", de toda uma classe de indivíduos "precarizados" que se reproduz há gerações enquanto tal (SOUZA, 2009, p. 21).

Jessé Souza argumenta que essa classe social desprivilegiada, chamada por ele ralé brasileira, não será definida de acordo com o poder financeiro de cada cidadão ou classe, mas, grosso modo, em relação a "transferências de 'valores imateriais' na reprodução das classes e de seus privilégios no tempo" (SOUZA, 2009, p. 19).

É sobre essa classe social e baseados nessa forma de entendimento de Jessé Souza, que contesta a divisão de classes baseada apenas em capital econômico para considerá-la como uma divisão em que se é preciso perceber "como os 'capitais impessoais' que constituem toda hierarquia social e permitem a reprodução da sociedade moderna, o capital cultural e o capital econômico, são também diferencialmente apropriados" (SOUZA, 2009, p. 21), que suscitamos levantar na literatura de João Antônio a escolha deliberada por essa parcela da população a que chamamos de desordem social. Segundo nossa hipótese, na primeira e na segunda história de seus contos está a representação da violência simbólica a que essas pessoas são acometidas, com o agravante de serem retratadas, em texto, segundo a lógica de um contato aparente entre aspectos da ordem social com a realidade dessa parcela de desordem. E é esse contato, movimento simulado, que nos fez adotar desordem social como o termo a designar essa camada da população na literatura de João Antônio. Pois se a organização estética e o entrecho do texto requerem um olhar para essas duas instancias sociais, a dialética da malandragem revisitada em seu uso, permite enxergar ordem e desordem em contato, ainda que aparente, no texto.

Zé Peteleco, Zé Vesgo, se quiserem, sempre foi mais de obedecer do que de levantar a cabeça e virar o jogo. Mas. Nesse tempo, por essas e outras, eu já estava mirado pelos ratos. O bom menino, desmilinguido e de nada, tinha quase as qualidades para se tornar 


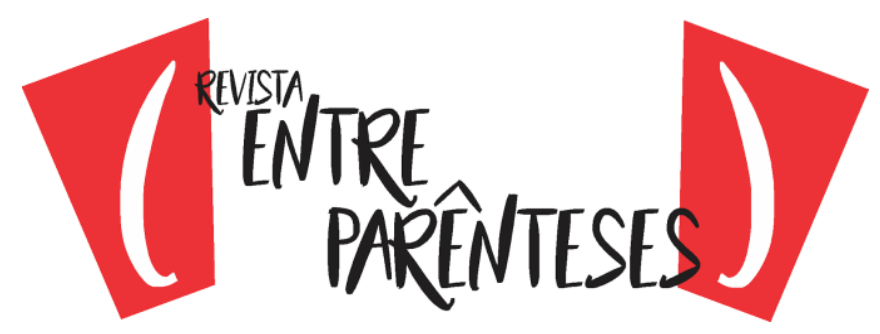

um homem de dar o serviço, um boca-mole. Não pelo que os da rua achavam, mas pelo que os tiras entendiam. [...] De assim, que pensei estar a caminho de uma amizade de valia com um rato legal, um boa gente da polícia. Que se chegou para mim e convidou, na malícia escondida. Crocodilagem.

- Vem cá, meu considerado (ANTÔNIO, 2012, p. 362).

O conto traz um retrato ocasional de um homem, sem nenhum destaque, praticante de pequenos achaques, que, por causa de uma amizade de interesses recíprocos com um policial, a quem chama de "rato", passa a dar informações para a polícia em troco de uma espécie de proteção e livre conduto. O movimento (aparente) entre ordem e desordem social está presente na própria organização estética do texto, porque é na aliança entre o bandido e o policial que se desenvolve o enredo do conto. A própria aliança, como se percebe, também uma relação entre agentes de um e outro polo - o policial, da ordem, e o bandido, da desordem. E essa relação ainda mais complexa, ainda mais profunda, porque simulada. O policial não é retratado como um representante da ordem, seu destaque e protagonismo só se dá na atuação que, em conjunto, faz com a desordem social. O aspecto de simulacro, de aparente, se dá na medida em que a ordem social, de fato, não se manifesta. Não há, para nenhum dos personagens do texto, uma possibilidade de emancipação. O policial, para além de sua farda, não tem poder de decisão, não tem poder de atuação por uma grande causa, mas apenas o operacional de quem não pensa o conflito, mas morre nele. Uma desordem social que, literalmente, se traveste de ordem, mas sem efeito de ordem social.

Nos referimos não à desordem do lícito e ilícito, de indivíduos com ou sem capital financeiro, mas à desordem de uma classe social oprimida todos os dias por uma violência simbólica que os limita a uma realidade de pouquíssimas realizações.

As diferentes classes e frações sociais estão envolvidas numa luta propriamente simbólica para imporem a definição do mundo social mais conforme aos seus interesses, e imporem o campo das tomadas de posições ideológicas reproduzindo em forma transfigurada o campo das relações sociais. Elas podem conduzir esta luta quer diretamente, nos conflitos simbólicos da vida quotidiana, quer por procuração, por meio da luta travada pelos especialistas da produção simbólica (produtores a tempo inteiro) e na 


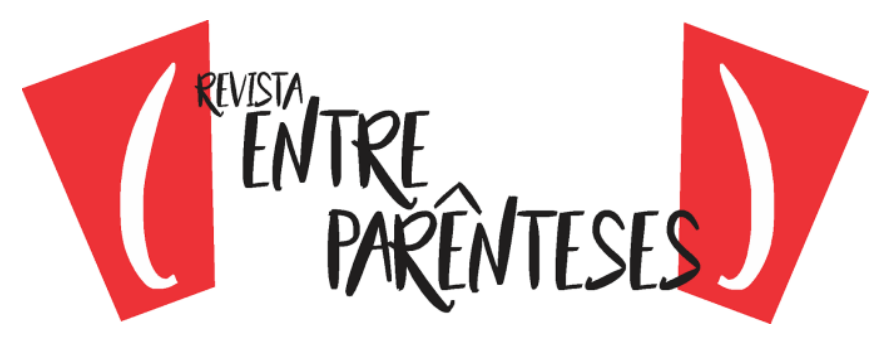

qual está em jogo o monopólio da violência simbólica legítima, quer dizer, do poder de impor - e mesmo de inculcar - instrumentos de conhecimento e de expressão (taxinomias) arbitrários - embora ignorados como tais - da realidade social (BOURDIEU, 2007, p. 1112).

É sobre essa desordem, a ralé brasileira, nossa desordem social, que argumentamos enxergar a atuação de João Antônio. E "Dedo-duro" é exemplo disso.

A impressão mais compulsivamente repetida por todos os jornais e por todo debate intelectual e político brasileiro contemporâneo é a de que todos os problemas sociais e políticos brasileiros já são conhecidos e que já foram devidamente "mapeados". Que não se perceba nenhuma mudança efetiva no cotidiano de dezenas de milhões de brasileiros condenados a um dia a dia humilhante devese ao fato de que a desigualdade brasileira vem de "muito tempo" e que não se pode acabar de uma penada com coisa tão antiga. As duas teses não poderiam ser mais falsas. Elas também não poderiam estar mais relacionadas. Elas formam o núcleo mesmo da "violência simbólica" - aquele tipo de violência que não "aparece" como violência -, que torna possível a naturalização de uma desigualdade social abissal como a brasileira. $\mathrm{Na}$ realidade, a "legitimação da desigualdade" no Brasil contemporâneo, que é o que permite a sua reprodução cotidiana indefinidamente, nada tem a ver com esse passado longínquo. Ela é reproduzida cotidianamente por meios "modernos", especificamente "simbólicos", muito diferentes do chicote do senhor de escravos ou do poder pessoal do dono de terra e gente, seja esta gente escrava ou livre, gente negra ou branca. Quando não se fala dessas formas "novas" e "modernas" de se legitimar a dominação cotidiana injusta e se apela a uma suposta e vaga continuidade com o passado distante é porque não se sabe do que se está falando, ainda que não se tenha coragem de admitir (SOUZA, 2009, p. 15).

\section{"Dedo e duro" e violência simbólica: a relação (às vezes aparente) entre ordem e desordem social}

"De-repentemente, urubu 'tá comendo gente. palavras (sic) ouvidas de um vagabundo do Méier" (ANTÔNIO, 2012, p. 359). É o que diz a epígrafe do conto “Dedo-duro" (1982), dando início ao texto literário já com uma pista do que se verá. O conto é narrado pelo protagonista, José, e traz a história de um processo e de um 


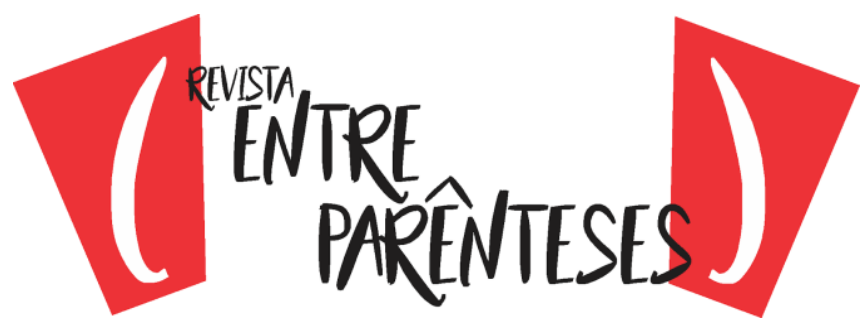

desejo de ascensão que, apesar de indicado, não se realizará efetivamente. A inversão entre ordem e desordem, que escancarará um esquema de ordem aparente e desordem social explcíta, antagônicos, também é parte integrante daquilo que dá destaque ao conto. José, que encurtado para Zé, que disfarçado, no principal de seus momentos, de Carioca, é o único ponto de vista do texto, lembremos, "limitado quase que exclusivamente às suas percepções" (LEITE, 1985, p. 43). O espaço é totalmente dedicado à ambiência, e toda ambiência do conto, construída na narração de José, Zé e Carioca, é a ambiência de desarranjo, desigualdade e desarmonia. É parte do que dá ao conto a tensão que o leitor sente sem saber exatamente de onde vem. E "[...] o grande conto breve condensa a obsessão do bicho, é uma presença alucinante que se instala desde as primeiras frases para fascinar o leitor, fazê-lo perder contato com a desbotada realidade que o rodeia, arrasá-lo numa submersão mais intensa e avassaladora" (CORTÁZAR, 2013, p. 231).

O conto é dividido em três partes: o ápice, com seu desfecho, na primeira parte; a apresentação do protagonista e o desenvolvimento do enredo, na segunda parte; e o problema principal, que fica momentaneamente sem solução, na terceira e última. O movimento do próprio texto, portanto, em conformidade com o movimento de Carioca, ou Zé, ou José, tudo em constante contato com o movimento entre a ordem, simulada, e a desordem social, quase palpável. No primeiro trecho, o desfecho, o protagonista é Carioca. No segundo, de apresentação, é José por uma linha e Zé Peteleco no restante. No terceiro, no qual o protagonista se vê defronte ao problema principal, é Carioca. Muito pouco se sabe sobre José.

Pé-rapado e cheio de irmãos, me escondi até os dezessete anos numa vilinha de Carapicuíba, colada à Aldeia dos Índios, sei lá por que esse nome. Até o centro, é uma hora batida de trem nos subúrbios da Sorocabana. Assim, fica pra lá dos subúrbios e o pessoal trambica no pesado; eu, não querendo nada. Aí, o velho me chamou na chincha, sacrifício tinha de ser de todos e mandou que me explicasse. Arrumava emprego ou caía no mundo. Caí na capital. E peguei, como quem começa, uns pedaços podres. Corri atrás, engraxando e esmolando, coisa de que não gosto de lembrar. Até um dia, então (ANTÔNIO, 2012, p. 361). 


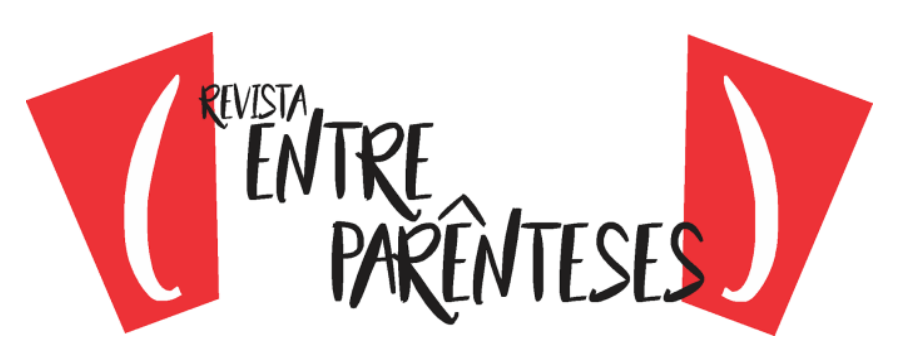

O que se pode empreender, sem que se perca o texto literário de vista, é que José foi uma criança e um adolescente de poucas possibilidades e aspirações. Escondia-se para lá dos subúrbios paulistanos até os dezessete, quando foi para São Paulo porque não queria trabalhar, não queria "sacrificar-se" pela casa, uma exigência do pai. Esconder é diferente de morar, e da casa de José, nada sabemos. Da mãe, se tinha ou não, também não temos notícia. Do pai, na única menção feita a ele, sabemos que chamou o filho para exigir que trabalhasse. E trabalho José não queria. "Saído do xadrez, não fazia uma semana, Cigano, [...] mandou pintar um quadro que pendurou na cabeceira da cama. Dizia lá: "Morro de fome mas não trabalho. Louvado seja Deus" (ANTÔNIO, 2012, p.359).

Vale ressaltar que 0

[...] "esquecimento" da "classe social", como segredo mais bem guardado da ideologia do senso comum, só pode ser adequadamente compreendido se separarmos cuidadosamente 0 conceito de classe social como fonte de todas as heranças simbólicas, valorativas, morais e existenciais que se passam de pais a filhos por laços de afeto, do conceito meramente econômico de classe como acesso a "renda". [...] O que os pais, ou figuras que os substituem, transmitem aos filhos, quer tenham consciência disso ou não, é toda uma visão de mundo e de "ser gente" que é peculiar à classe a que pertencem. $O$ que a classe média ensina aos filhos é comer nas horas certas, estudar e fazer os deveres de casa, arrumar o quarto, evitar que os conflitos com amigos cheguem às vias de fato, chegar em casa na hora certa, evitar formas de sexualidade prematuras, saber se portar em ambientes sociais etc. As famílias da classe média ensinam, portanto, "valores" de uma dada "classe", que são os valores da autodisciplina, do autocontrole, do pensamento prospectivo, do respeito ao espaço alheio etc. Que esse aprendizado seja "esquecido" ou não tematizado deve-se ao fato de que ele é transmitido afetiva e silenciosamente no refúgio dos lares. $O$ aprendizado familiar é afetivo, ele só existe porque existe também a dependência e a identificação emotiva e incondicional dos filhos em relação aos pais (SOUZA, 2009, p. 44-45).

Sobre sua formação como indivíduo, para além desse momento inicial com o pouco que sabemos de sua família, ainda podemos empreender como se desenvolveu chegada e estabelecimento na cidade, que foi 


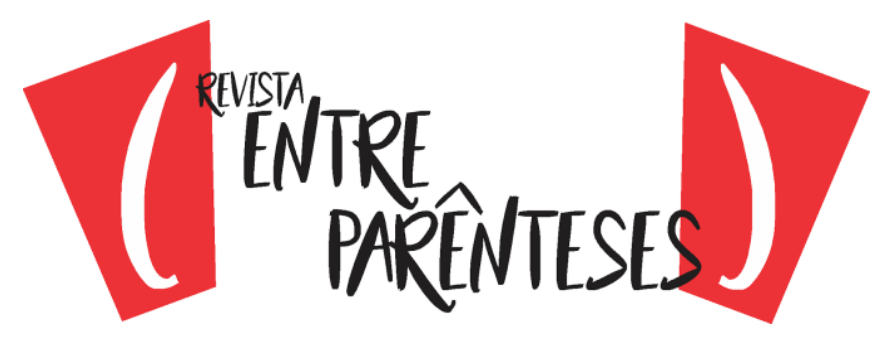

[...] apanhando e entregando roupa num tintureiro da rua do Triunfo, na Boca do Lixo. Era novo, mirrado, mas acostumado. Sabia dormir com percevejo por perto e foi ali que aprendi a conhecer os tipos de malas. Que na barra se concentrava gente de um tudo mexendo com o ramo variado; era putaria, tráfico, jogo, batifundo, assalto, virações. Isso. Fracote, pequeno, mas no ambiente (ANTÔNIO, 2012, p. 361).

E, também, além disso, neste outro trecho:

Olhem aí, se eu disser que sou homem forte ou essas coisas, estarei mentindo. E em historiada de mulher, aqui miúdo, a sensação me vem, várias vezes, de ser pouco homem diante de certos mulherões que vejo passar. Nem sou bom jogador, não aprendi furto e nem soube, pelo esforço certeiro - e meu - descolar uma maconha, uma bolinha, um brilho de cocaína. Não me dei bem no trato com as coloridas na sinuca, não fui um linha-de-frente no jogo do carteado, nem bom escrevedor de jogo do bicho, pego mal nas corridas de cavalo, não consegui fazer meio de vida nos entorpecentes. Não pertenci à patota dos rapazes fortes da leva mais moça saídos do Juizado de Menores, espertos, sabendo um tudo e considerados de todos, inda mais da polícia. Porque pivete não hesita, saca a arma e aperta ali o otário que estiver na frente vai pra chácara dos pés juntos. Pivete é fera. Zé Peteleco, Zé Vesgo, se quiserem, sempre foi mais de obedecer do que de levantar a cabeça e virar o jogo (ANTÔNIO, 2012, p. 362).

Isso é tudo. Deste momento em diante, transcorrido apenas um pequeno pedaço do conto, já seremos introduzidos ao principal fato do texto, o coração do conto, motivo de todo seu efeito6: a amizade de Zé Peteleco e Sebastião Pé de Chumbo, "seu" policial. Desde quando era "fraco", estava já no ambiente de trambiques e desordem. Desde lá, aprendendo o ofício da desordem. Os seus amigos e aqueles com os que conviviam estavam todos imersos em uma vida de nenhuma realização pessoal.

[...] é sobre essa "classe de indivíduos" que nasceram sem o "bilhete premiado" de pertencerem às classes alta e média. $O$ privilégio positivo do "talento inato" das classes alta e média é transformado em privilégio negativo de toda uma classe social que se produz e se reproduz como classe de indivíduos com um "estigma inato". Essas

\footnotetext{
${ }^{6}$ Ver: POE, Edgar Allan. Filosofia da composição. Poemas e Ensaios. São Paulo: Globo, 1999. Disponível em: http://paginapessoal.utfpr.edu.br/mhlima/FILOSOFIA\%20DA\%20COMPOSICaO\%20Poe.pdf/view.
} Acesso em: 12 jul. 2016. 


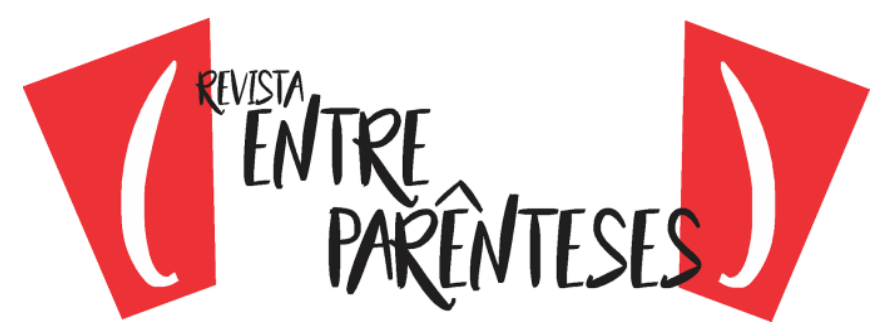

são as pessoas que estão sempre a um passo - ou com os dois pés dentro - da delinquência e do abandono. Essa classe é moderna. Não é o "jeitinho brasileiro" de 500 anos atrás que a cria, mas a impossibilidade afetiva, emocional, moral e existencial de "incorporação" dos pressupostos indispensáveis à apropriação tanto do capital cultural quanto de capital econômico. [...] Ao invés da oposição clássica entre trabalhadores e burgueses, o que temos aqui, numa sociedade perifericamente moderna como a brasileira, como nosso "conflito central", tanto social quanto político que subordina em importância todos os demais, é a oposição entre uma classe excluída de todas as oportunidades materiais e simbólicas de reconhecimento social e as demais classes sociais que são, ainda que diferencialmente, incluídas (SOUZA, 2009, p. 25).

À José resta a impossibilidade, quase sem motivo, diluída, muito difícil de rastrear origens e motivos, de ser policial. Por que não conseguira? O trecho:

\begin{abstract}
Estou mordido pelas falas do tira. E não me é custoso meter na cabeça que também, lá no fundo, sempre me arranhou a vontade de ser investigador. Detetive. Sendo um zé-mané qualquer, um péinchado, sem escola e sem padrinho, sem goma ou endereço fixo, nunca tive jeito de mandar à frente qualquer plano. De repente, um cana me vem, faz que se engraça, descubro que ser dedo-duro é caminho. Palmilhado direitinho, atenção e juízo, pode desembocar num emprego bom (ANTÔNIO, 2012, p. 364).
\end{abstract}

"O que nos afasta das sociedades "moralmente superiores" é que exploramos, aceitamos e tornamos fato natural e cotidiano conviver com gente sem qualquer chance real de vida digna sem ter nenhuma culpa nisso" (SOUZA, 2015, p. 245). A personagem que não tinha endereço fixo, que se escondeu na infância, que conviveu com virações de todos os tipos quando adolescente, não conseguira ser policial. E almejava. Através dessa impossibilidade deu-se a relação com Sebastião Pé de Chumbo, que Ihe renderia uma possibilidade de colocação no Departamento, certa proteção, algum dinheiro, e algum conforto social; todos elementos que dignificam socialmente um sujeito, obtidos - ou quase obtidos - através de uma organização de desordem social característica da sociedade brasileira; que atinge uma parte específica de nossa população, estratificando e definindo lugar de mundo.

Ao invés de oposição clássica entre trabalhadores e burgueses, o que temos aqui, numa sociedade perifericamente moderna como a 


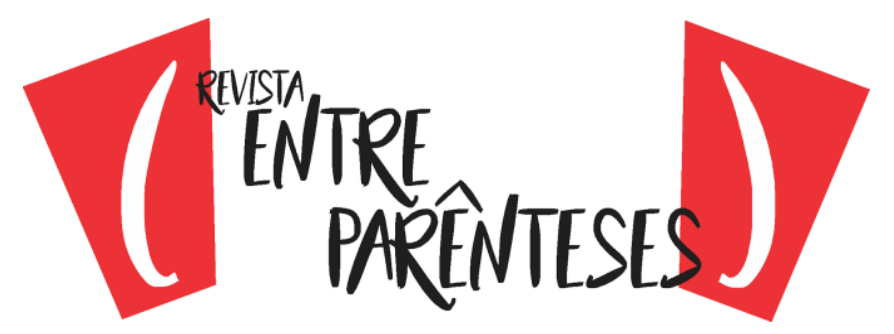

brasileira, como nosso 'conflito central', tanto social quanto político e que subordina em importância todos os demais, é a oposição entre uma classe excluída de todas as oportunidades materiais e simbólicas de reconhecimento social e as demais classes sociais que são, ainda que diferencialmente, incluídas (SOUZA, 2009, p. 25).

Carioca entregou à polícia toda a curriola de bandidos que acabou por incomodar mais do que era "permitido". Marcou um encontro com eles, simulou que seria comprador dos eletrônicos frutos de um roubo e, com cuidado para não ser descoberto, fez-se aliado. Levou os policiais até o local combinado e acabou por levar a todos presos, inclusive ele, que é como se simula que o dedo-duro não seja dedo-duro. As vítimas dos roubos, comerciantes do subúrbio, eram "escandalosos" no reclamar, e por causa de uma declaração no noticiário da televisão, acabaram por criar um movimento que foi parar nos jornais. O barulho foi tanto que a polícia não tinha alternativa senão agir. Era o grande caso de Carioca, o que poderia the render um emprego como policial. Esse é o único momento em que a ordem, verdadeira, ordem social, de fato aparece no texto.

E, de Carioca, enfiei-me num subúrbio para fazer o bom trampo. Assaltos infestavam o lugar e a ladroeira ia de cambulhada. Os comerciantes botavam a boca no trombone e, escandalosos, bundeavam; acabaram chiando no noticiário da televisão. Um desses loques apitou que sua casa foi assaltada quinze vezes num mês. Só que se esqueceu, o bom bunda-mole, de agradecer a Deus por ter escapado com vida. Mas fedeu. Descalabro arrepiou e os jornais gritando (ANTÔNIO, 2012, p. 371).

E ainda

Conseguisse um daqueles, apenas um seria ponto grande a meu favor na polícia, sucesso. Aquele, debaixo de tortura, traria o outro. $\mathrm{O}$ segundo traria o terceiro, e assim, viria o bando. Seria a chamada carambola, todos acabariam em galera mais os receptadores. Os jornais iam calar a boca e a gente, molhar a mão na grana. Meu medo foi sumindo, ganhei força. E armei (ANTÔNIO, 2012, p. 374).

Curioso é como do texto se retira as correlações entre os conceitos de ordem e desordem. Aparentes e verdadeiros. Zé Peteleco já tinha sua amizade confirmada com o policial na altura de acontecerem os assaltos de que reclamaram 


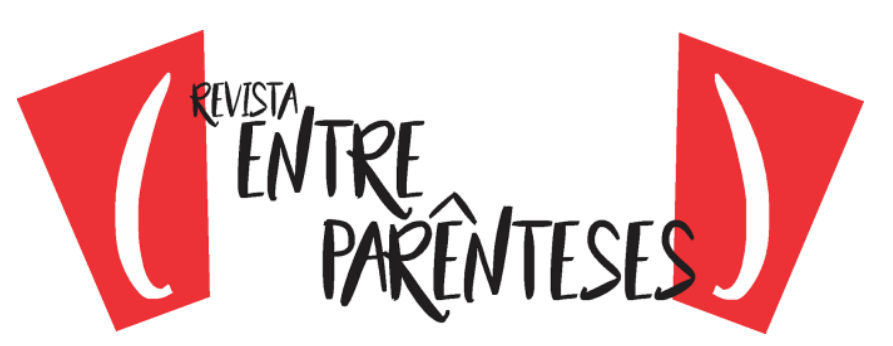

os comerciantes. Mesmo assim, ainda que tenha tido sucesso em suas observações, ainda não havia conseguido o trabalho e a colocação que almejava. As observações eram certeiras, sim, mas pequenas ainda. Fez prender Tição, um bandido que roubara a pastelaria de um japonês, por exemplo. Nenhum interesse social havia nessa prisão. Tição era pequeno. A pastelaria era pequena. $O$ japonês era pequeno. A diferença, no caso de Carioca, é o apelo que se faz a partir de uma reclamação nos jornais e na televisão. Naquele momento o contingente de policiais será maior, o esforço será maior e o impacto será maior. À ordem não importa quantos japoneses serão ou não serão assaltados, importa que a televisão e os jornais não repercutam assaltos sem solução; essa ocasião é depreciativa para o governo, que demonstra falta de comando, para os cidadãos, que não se sentem seguros e, por conseguinte, não tenderiam a continuar votando no mesmo tipo de governo, e aos policias que comandam a corporação, porque efetivamente seriam cobrados graças às primeiras duas razões. Este é o único contato do protagonista, seja como Zé, como Carioca ou como José, com a ordem social. A ausência dela, como se viu na formação do personagem, também uma espécie simbólica de violência.

Zé não queria trabalho, se encontrou com uma mulher e ficou pela Boca do Lixo. Por lá aprendeu como se virar, sobrevivia. No momento de desenvolvimento do enredo, entretanto, revela o desejo de arrumar trabalho, porque "malandro não tem futuro, seu passado é ruim e o presente um cocô. Futuro, quando bom, é morar na Detenção" (ANTÔNIO, 2012, p. 362). O trabalho, portanto, será sua relação com uma ordem aparente. Mas o que ele faz para viver, o que consegue como ocupação, é entregar à polícia os crimes dos outros. Seu trabalho é informal, ilegal, e não lhe confere nenhum tipo de ascensão. Quando dá certo e o dedo-duro ganha um lugar, sabemos

[...] que a Secretaria não dá verba aos cachorrinhos, mas manda imprimir e lhes fornece, na moral, umas carteirinhas de agente reservado. Já a caixinha passada pelos tiras, o vale branco, inda mais pela ratatuia ligada a furtos e entorpecentes, varia, estica e 


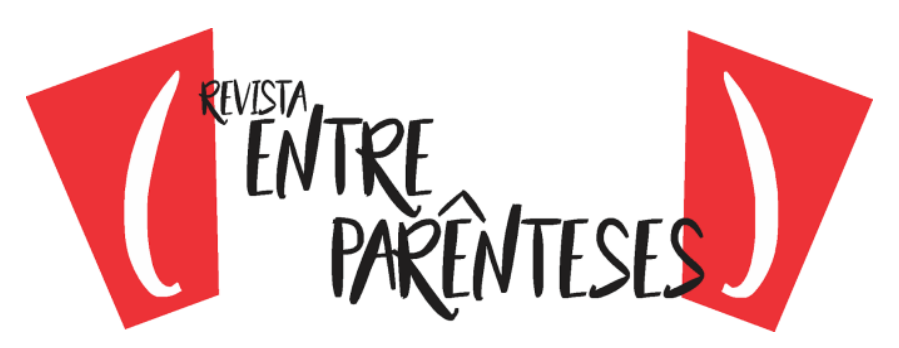

encurta, mas é sagrada e segredo se o serviço é quente (ANTÔNIO, 2012, p. 364).

Uma ordem que é só aparente, e nada real. Ainda que consiga um trabalho, ainda que consiga um lugar, ainda que tenha alguma posição na polícia, será clandestina. Não terá salário porque a Secretaria não manda dinheiro aos dedos-duros, mas o valor que sai de operações ilegais não faltará. É como uma ordem que nunca se apresenta a um homem que sempre quis ser policial, apesar de, como lembramos, não querer trabalhar aos dezessete anos. Uma ordem que usa a desordem como caminho para suas conclusões, sustentada por essa ordem, por uma lógica ilegal de desordem. É a (des)organização social brasileira, externa aos textos literários, funcionando como organização estética do texto, através da conversa entre uma ordem aparente e uma desordem social manifestada. "Esta não é afirmada abstratamente [...], nem apenas ilustrada com exemplos, mas sugerida na própria composição do todo e de suas partes, na maneira por que organiza a matéria, a fim de lhe dar uma certa expressividade" (CANDIDO, 20020, p. 7).

Quando fazemos uma análise deste tipo, podemos dizer que levamos em conta o elemento social, não exteriormente, como referência que permite identificar, na matéria do livro, a expressão de uma certa época ou de uma sociedade determinada; nem como enquadramento, que permite situá-lo historicamente; mas como fator da própria construção artística, estudado no nível explicativo e não ilustrativo (CANDIDO, 2000, p. 7).

Essa manifestação se naturaliza conforme se percebe, na relação de amizade entre o policial e o dedo-duro, no jogo entre ordem aparente e desordem social explícita, o próprio movimento do texto literário. A polícia resolve crimes de acordo com sua relação com as personagens que vivem no ambiente do crime. "Ouço, quando em quando, que a alcaguetagem é a alma da polícia e sem a delação o campo de ação da dona-justa desmilinguiria" (ANTÔNIO, 2012, p. 366). Uma relação dependente. Se se olha para a farda, associa-se o policial à ordem, mas que ordem é essa que só atinge seus objetivos de aliada à desordem? É neste momento que a correlação entre um polo e outro, da maneira como Candido referenciou, também aparece no texto, deixando claro que essa relação ainda se 


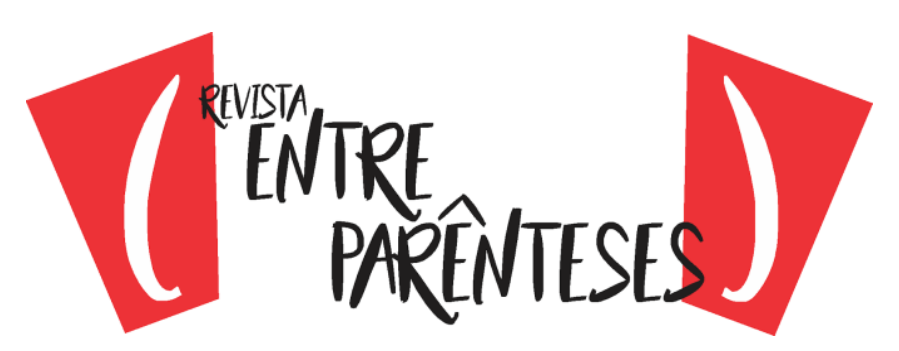

manifesta, como aquela que sugerimos imputar, no cotidiano brasileiro. Apesar de aparente, a farda nos faz ver a ordem em cruzar a linha do lícito e conluiar com a desordem, também do ilícito. Desordem que busca colocação como ordem.

\begin{abstract}
Para os caras das curriolas, eu era sujeitinho. Chué, mixuruco, dos que quando não bebidos, mais ouvem que falam, covardezinho e, disfarçado, desbaratinado, arisco de passar por malandrinho. Já para os homens, os canas, o meu quieto engrupido poderia render se infiltrado na campana, a fim de espionar em várias situações. De assim, que pensei estar a caminho de uma amizade de valia com um rato legal, um boa gente da polícia. Que se chegou para mim e convidou, na malícia escondida. Crocodilagem:
\end{abstract}

- Vem cá, meu considerado (ANTÔNIO, 2012, p. 362).

A amizade dos dois, como tudo no texto e tudo a respeito dele, também carrega em si um movimento. Há o momento em que Zé Peteleco percebe, sem que Ihe digam, a eminência de ser abandonado por seu policial sob o pretexto de ter deixado o trabalho de lado. O risco à sua segurança é imenso, na desordem não há escapatória para alguém que transita com a ordem, "Lá, sei que perdão não tem para a palavra cagueta. Quem fala morre. É rebosteio", e na própria ordem também não haverá, se cair: "Sei também que se tomar uma cadeia quente, de verdade, e me cair o disfarce, não sairei o vivo, além do pau, da tortura e da enrabação. Malandro que é malandro não deixa por menos (ANTÔNIO, 2012, p. 367). E essa vida de riscos não incomoda mais que a vida de impedimentos, porque "Morar em Carapicuiba numa vila encostada à Aldeia dos Índios comendo pó e amassando barro vermelho não é viagem melhor e é mais escroto. Camela-se às pampas. Garanto" (ANTÔNIO, 2012, p. 368).

$E$ é na relação entre os dois que se percebe um último aspecto a respeito de "Dedo-duro". Seu aspecto de singularidade, de tomada de posição política, e a ausência de força e profundidade de Sebastião Pé de Chumbo. Todo texto literário remete a um aspecto estético e a outro ideológico. Sebastião Pé de Chumbo praticamente não fala, não aparece e não decide nada. Suas nuances enquanto um profissional de uma polícia falida, sem condições de resolver os crimes e em contato constante com o ilícito e com a desordem, como em Candido, e com a desordem 


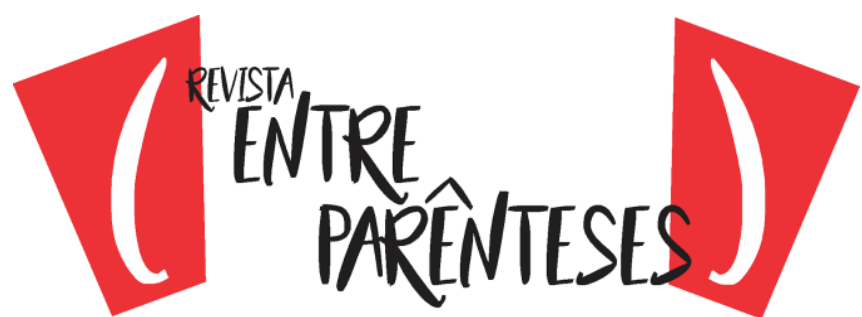

social que levantamos, são ignoradas pelo narrador e, por conseguinte, por João Antônio, que empresta sua voz, por um corpo-a-corpo com a vida brasileira, aos seus personagens.

O elemento que mais me leva a acreditar em Malagueta, Perus e Bacanaço como coisa viva se arruma exatamente no fato de que vi meus jogadores de sinuca, viradores, vadios, vagabundos, merdunchos do ponto de vista deles mesmo. E não do escritor. No meu caso particular, até por questões de vida, não poderia enfrentálos sob nenhuma outra ótica (ANTÔNIO, 1975, p. 150).

É a escolha de João Antônio, da qual já falamos, de escrever seus textos, com intenção interventora, a partir da perspectiva única de uma desordem social brasileira, em favor dessa mesma desordem social - o povo desprivilegiado socialmente. Essa perspectiva, justificativa que se faz através do ponto de vista, não deixa de enfraquecer e fazer de Sebastião Pé de Chumbo um policial caracterizado e sem profundidade. Não sabemos de seu desenvolvimento, o que enfraquece a narrativa e a exime da possibilidade de mais. Daí poderia sair, por exemplo, a perspectiva de uma também desordem social - uma vez que já sabemos que a farda representa apenas uma ordem aparente - em seus interesses e desafios éticos no conluio com aquilo que é fora da lei.

Os dilemas de Zé Peteleco são expostos, um a um: a falta de estrutura de sua formação; o desafio de viver na cidade; a relação com os malandros; o desejo e só desejo de se tornar policial; os riscos e vantagens de ser um dedo-duro, mas de Sebastião nada além de um nome e uma frase "Vem cá, meu considerado" (ANTÔNIO, 2012, p. 362). Essa constatação, que consideramos deslize, acaba por servir como um outro sintoma do movimento entre ordem e desordem que João Antônio emprega em seus textos. Em um texto de tomada de posição pela desordem, no momento em que a ordem é focalizada, não há movimento, não há encostar, não há nada. A ordem, ainda que simulada, não aparece encostada ou conluiada com a desordem, a não ser pelos olhos da própria desordem. Sabemos do acordo de Zé Peteleco e Sebastião, mas pela perspectiva única de Sebastião. O levante de João Antônio, por seu povo, acreditamos ser também a favor do policial 


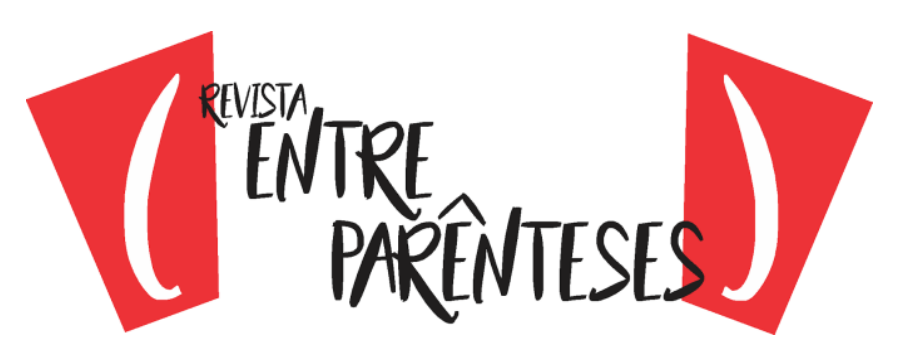

que, a bem da verdade, é um agente em uma luta sem fim. Na ausência de profundidade do policial, há a probabilidade de uma denúncia e de um caminho: a polícia silenciada, sem voz, sob a perspectiva da desordem, mostra que a desordem é focalizada por essa ordem apenas quando se faz necessária - que é quando a ordem permite um passar por cima da lei. Uma outra possibilidade, entretanto, é a do esvaziamento deste aspecto do texto, da riqueza que poderia vir de um enfrentamento e aprofundamento da relação entre Sebastião e Zé Peteleco, não necessariamente a partir da perspectiva do primeiro, mas com o olhar do narrador, ao menos, voltado para ele e para as relações que tinham ou para a própria relação de dedo-duro e policial, porque cada um tem seu próprio "informante" (ANTÔNIO, 2012, p. 366).

Em nossos dias, Forster retomou a distinção de modo sugestivo e mais amplo, falando pitorescamente em "personagens planas" (flat characters) e "personagens esféricas" (round characters). "Na sua forma mais pura, são construídas em torno de uma única ideia ou qualidade; quando há mais de um fator neles, temos o começo de uma curva em direção à esfera. [...] Tais personagens são facilmente reconhecíveis sempre que surgem"; "são, em seguida, facilmente lembradas pelo leitor. Permanecem inalteradas no espírito porque não mudam com as circunstâncias" (CANDIDO, 2005, p. 62-63).

A complexidade da relação, na perspectiva de Zé Peteleco, fica evidente não só nos riscos que enfrentava, mas na expectativa que depositava naquilo. No desejo infantil de ser policial à necessidade adulta de se incorporar ao Departamento, e ainda assim, desliza, "só quando de porre, bode ou grogue mesquinho" e toma pra si, como agente da desordem, um gostinho: "Na birosca, protegiro pelo babilaque que carrego, expondo, ostento e costumo dar, em voz alta, uma destas: - Aqui é cana! Aqui é polícia [...] Mas isso é lá no subúrbio, onde moro. $\mathrm{Na}$ cidade, numa boca pesada ou num botequim de favela, dou para me encolher" (ANTÔNIO, 2012, p. 368).

A colocação é mais que um desejo, uma necessidade.

E a gana de ser policial me correndo por dentro. Não quero nem saber se, na área, um e outro cara de juízo me alerte que, na 


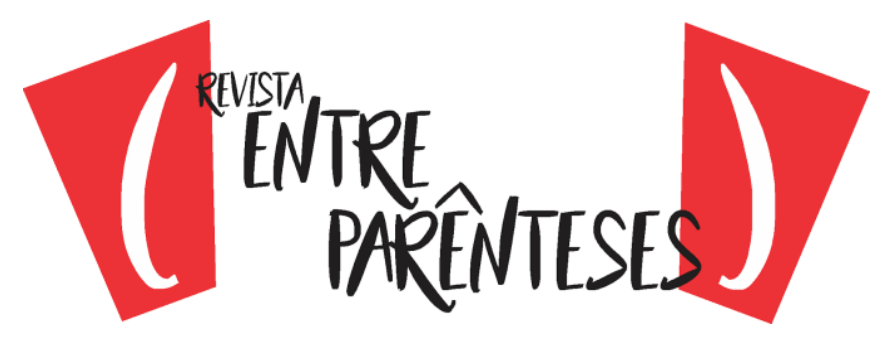

continuação da pegada, esta vida não compensa. Na batida em que vou, está me interessando é andar de algemas e máquina niquelada na cintura, arrotando umas grandezas muito à vontade e criando nome no meio dos majorengos (ANTÔNIO, 2012, p. 364).

Ou um sonho distante.

Aqui na barra, tanta coisa vira façanha e cada peripécia fica lenda, faz memória. Maioria é figuração. Corre aí um papo, quando em quando, que tem sujeito de bom piso hoje na polícia começado como cagueta. E já não sou mais carne, nem peixe, vou achando a mumunha para chegar a policial, um dia, é endedando, engessando, apresentando, descobrindo, entregando a jato e me fazendo notar pelos homens. As notícias são confusas e mais fácil é desconfiar delas, que nem sou homem de discutir fundamentos. O que está aí é porque aí está. O diabo é se situar dentro disso (ANTÔNIO, 2012, p. 366).

E como se uma interrupção de todo o movimento que vimos, o fim do conto - e das possibilidades no pequeno mundo de Carioca.

\section{Considerações finais}

Flannery O'Connor, a grande narradora norte-americana, contava uma história muito divertida. "Tenho uma tia que pensa que nada acontece num relato, a menos que alguém se case ou mate outro no final. Escrevi um conto em que um vagabundo se casa com a filha idiota de uma velha. Depois da cerimônia, o vagabundo leva a filha em viagem de núpcias, abandona-a num hotel de estrada e vai embora sozinho, conduzindo o automóvel. Bom, essa é uma história completa. E, no entanto, não pude convencer minha tia de que esse era um conto completo. Ela queria saber o que acontecia com a filha idiota depois de abandonada." [...] E, pelo visto, a tia de Flannery não encontrou o sentido dessa história. O final põe em primeiro plano os problemas de experiência e nos defronta com a presença de quem espera o relato. Não se trata de alguém externo à história (não é a tia de Flannery), mas de uma figura que faz parte da trama. No conto de O'Connor ("The life You Save May Be Your Own"), é a velha sovina que quer se livrar da filha demente: é ela quem recebe o impacto inesperado do final; a ela destina-se a surpresa que não se narra. E também certamente a moral. Perde o carro e não consegue se desvencilhar da filha (PIGLIA, 2004, p. 99). 


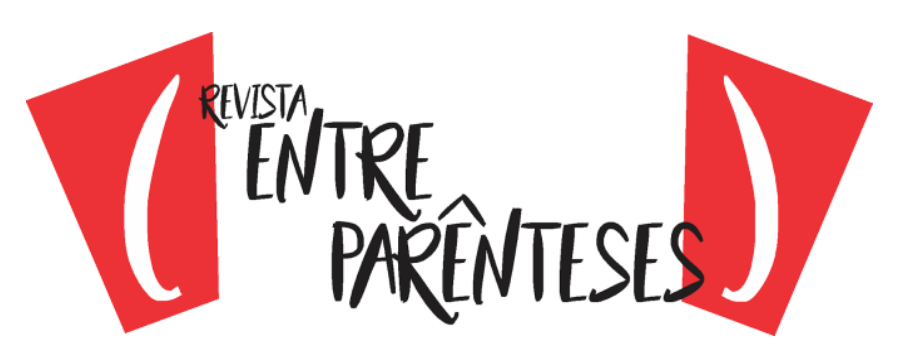

O final do conto, que na verdade é sua primeira parte, é um desfecho capenga. Termina por entregar os bandidos, mas não põe fim à busca de Carioca. Não sabemos se ele vai conseguir seu lugar no Departamento. Como para a tia de Flannery O'Connor, talvez "Dedo-duro" não tenha final. E se essa impressão nos arremata é porque, justamente, não há. Mais uma manifestação estética de um desígnio social que atinge uma porção de Josés, Zés e Cariocas e organiza o texto, colocando seu final logo no começo, sem um desfecho satisfatório - ainda que o leitor não seja capaz de saber disso no momento primeiro da leitura. É a violência simbólica que perpassa todo o conto sob a organização de um jogo desleal entre uma ordem social simulada e uma desordem social manifestada, fazendo da desordem o único caminho possível, movimento natural de seu protagonista e narrador, que revela a opção de João Antônio; totalmente aliada a seu projeto literário, tanto no trabalho quanto no desenvolvimento de uma prosa que fale para e por aqueles que compõem a camada menos favorecida do povo brasileiro.

Foi ao revisitar os conceitos de ordem e desordem e ao permitir o seu atualizar social, que fomos capazes de enxergar o movimento do texto, apenas ilusório e perceber, na primeira e na segunda história do conto (PIGLIA, 2004) não só uma organização textual condizente, eficiente em sua forma, mas também a função social de seu texto, manifestada por completa.

\section{REFERÊNCIAS}

ANTÔNIO, João. Corpo-a-corpo com a vida. In: Malhação do Judas

Carioca. Rio de Janeiro: Record, 1975. p. 141-151. Dedo duro. In: . Contos reunidos. São Paulo: Cosac Naify, 2012.

BOURDIEU, P. Sobre o poder simbólico. In: Janeiro: Bertrand Brasil, 2007. p. 7-16. O poder simbólico. Rio de CANDIDO, Antonio. Na noite enxovalhada. In: ANTÔNIO, João. Contos reunidos. São Paulo: Cosac Naify, 2012. p. 577-582 


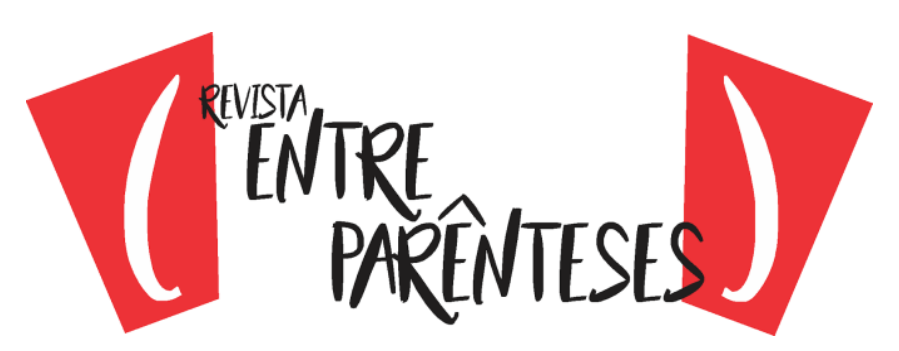

A nova narrativa. In: A educação pela noite e outros ensaios. Rio de Janeiro: Ouro sobre azul, 2006. p. 241-260.

. Literatura e sociedade: estudos de teoria e história literária. São Paulo: T. A. Queiroz, 2000.

. Dialética da malandragem. Revista do Instituto de Estudos Brasileiros, n. 8, p. 67-89, 1970.

et al. A personagem de ficção. São Paulo: Perspectiva, 2005.

CORTÁZAR, Julio. Do conto breve e seus arredores. In:

Valise de Cronópio. Rio de Janeiro: Record, 2013. p. 227-237.

LEITE, Ligia Chiappini Moraes. O foco narrativo (ou A polêmica em torno da ilusão). São Paulo: Ática, 1985.

ORNELLAS, Clara Ávila. Aspectos iniciais da trajetória literária de João Antônio, Via Litterae, v. 3, p. 145-149, 2011.

PIGLIA, Ricardo. Formas breves. São Paulo: Cia das Letras, 2004.

POE, Edgar Allan. Filosofia da composição. Poemas e Ensaios. São Paulo: Globo, 1999.

Disponível

em:

http://paginapessoal.utfpr.edu.br/mhlima/FILOSOFIA\%20DA\%20COMPOSICaO\%20

Poe.pdf/view. Acesso em: 12 abr. 2018.

SCHWARZ, Roberto. "Pressupostos, salvo engano, de "Dialética da malandragem". In: . Que horas são. São Paulo: Companhia das Letras, 1979. v. 2, p. 129155.

SILVA, J. C. B.. João Antônio e seu projeto literário: corpo-a-corpo com o Brasil? In: XI SEMINÁRIO INTERNACIONAL DE HISTÓRIA DA LITERATURA, 11., 2015, Porto Alegre. Anais... Porto Alegre: EDIPCURS, 2015. p. 1-9.

SOUZA, Jessé. A ralé brasileira: quem é e como vive. Belo Horizonte: editora UFMG, 2009.

A tolice da inteligência brasileira: ou como o país se deixa manipular pela elite. São Paulo: LeYa, 2015.

Recebido em: 30/04/2018 